\title{
Andersen i Carofiglio. Literacko-filozoficzny portret człowieka i miasta
}

\author{
Andersen and Carofiglio. Italian cities in the novels \\ of the nineteenth and twenty-first centuries
}

\section{Paweł WOJCIECHOWSKI ${ }^{1}$}

Uniwersytet w Białymstoku

\begin{abstract}
The text presents selected images of Italian cities present in the novels of Hans Christian Andersen and Giacomo Carofiglio. Rome, Naples, Amalfi, Pompeii, and Bari were read here from two perspectives: bucolic and pessimistic, which allowed to recreate the authors' attitude towards the cultural phenomenon of the city. It was emphasized that the authors writing in the two early centuries: the nineteenth (Andersen) and the twenty-first (Carofiglio) - read the cities of Italy in parallel through experiences of individual sensuality, sensitivity, contemplation and perception. Literature material was also interpreted in the context of the philosophies of Pascal, Bergson, Nietzsche and Deleuze.

Keywords: literature, 19th and 21st century novels, city; Hans Christian Andersen, Giacomo Carofiglio, Rome, Naples, Amalfi, Pompeii, Bari, philosophical anthropology

\section{Streszczenie}

W tekście pokazano wybrane wizerunki miast włoskich obecnych w powieściach: Hansa Christiana Andersena i Giacomo Carofiglio. Rzym, Neapol, Amalfi, Pompeje, Bari zostały tu odczytane w dwóch perspektywach: bukolicznej i pesymistycznej, co pozwoliło odtworzyć nastawienie autorów do fenomenu kulturowego miasta. Uwyraźniono, iż autorzy piszący w dwóch początkach wieków: XIX (Andersen) i XXI (Carofiglio) - paralelnie czytali miasta Italii poprzez doświadczenia indywidualnej sensualności, wrażliwości, kontemplacji i percepcji.
\end{abstract}

1 https://orcid.org/0000-0001-8826-5318

Uniwersytet w Białymstoku, Wydział Filologiczny

p.wojciechowski@uwb.edu.pl 
Materiał literaturowy zinterpretowano również w kontekstach filozofii Pascala, Bergsona, Nietzschego oraz Deleuze'a.

Słowa kluczowe: literatura, powieść XIX i XXI wieku, miasto; Hans Christian Andersen, Giacomo Carofiglio, Rzym, Neapol, Amalfi, Pompeje, Bari, antropologia filozoficzna

Miasta „posępny obraz zajmował wszystkie moje myśli, a stan mego umysłu nadawał mu mocny koloryt"2

\section{Włoskie miasta Improwizatora}

Dzisiaj mało kto pamięta, iż eminentny reprezentant literackiego romantyzmu skandynawskiego - Hans Christian Andersen $(1805-1875)^{3}$ pisał nie tylko dla dzieci. Namysł badawczy kieruję zatem w stronę Andersena - literata, mniej kojarzonego $\mathrm{w}$ powszechnej (by nie powiedzieć masowej) przestrzeni lekturowej $\mathrm{z}$ konkretnym gatunkiem pisarstwa, takim jak powieść, epistolografia, diarystyka czy szkic literacki, jak również z określoną topiką, sztandarowymi toposami literackimi, takimi jak podróż czy miasto. W tekstach $\mathrm{z}$ takimi loci communes, obecnymi $\mathrm{w}$ dorobku pisarskim autora $\mathrm{z}$ Fionii, interesuje mnie przede wszystkim figura miasta, wizerunek punktów miejskich odwiedzanych przez Andersena w trakcie jego wojaży po dziewiętnastowiecznej Europie.

Z deskrypcjami miast spotykamy się już w pierwszej powieści Duńczyka zatytułowanej Improwizator, wydanej w roku 1835, w Kopenhadze ${ }^{4}$, pełnej

2 Andersen H. Ch. (2017). Improwizator, tytuł oryginału: Improvisatoren, przekład H. Feldmanowski. Kraków: Wydawnictwo MG, s. 285.

${ }^{3}$ Zob. Wullschläger, J. (2005). Andersen. Życie baśniopisarza, tłum. M. Ochab, fragmenty baśni, listów i dzienników Andersena w przekładzie B. Sochańskiej. Warszawa: Wydawnictwo W. A. B.; Dalager S. (2007). Podróż w błękicie. Powieść o Hansie Christianie Andersenie, tłum. B. Sochańska, J. Tamborska. Warszawa: Spółdzielnia Wydawnicza „Czytelnik”; Andersen 200 lat. (2006). red. H. Dymel-Trzebiatowska, E. Mrozek-Sadowska, Seria Nordicum. Gdańsk: Wydawnictwo Pressfabryka; Andersen H. Ch. (2003). Autobiografia. Baśń mojego życia, tłum. I. Chamska, Seria Znani Nieznani. Łódź: Wydawnictwo Ravi; Andersen H. Ch. (2014). Dzienniki 1825-1875, wybór, przekład i opracowanie B. Sochańska. Poznań: Wydawnictwo Media Rodzina; Andersenowskie inspiracje $w$ literaturze $i$ kulturze polskiej. (2017). red. H. Ratuszna, M. Wiśniewska, V. Wróblewska. Toruń: Wydawnictwo Naukowe UMK.

${ }^{4}$ Korzystam z wydania: Andersen H. Ch. (2017). Improwizator, dz. cyt.; wszystkie przywołania $\mathrm{w}$ tekście pochodzą $\mathrm{z}$ tego wydania, cytat oznaczam $\mathrm{w}$ nawiasie wielką literą I oraz odpowiadającą mu paginacją. Pierwsze polskie wydanie tej powieści: Andersen H. Ch. (1857). Improwizator, tom 1 i 2, tłum. H. Feldmanowski. Poznań: Wydawnictwo L. Merzbach. 
niezwykle pięknych, wyjątkowo malowniczych opisów Italii XIX stulecia. Andersen z charakterystycznym dla siebie wyczuciem i wrażliwością opisuje miejsca (np. plaże, regiony pozamiejskie, Wezuwiusza) i miasta włoskie ${ }^{5}$, chwyta ich niezwykłość, niezwyczajny nastrój, rozległą warstwę sensualnego doświadczania ich specyficzności. Każde z odwiedzanych przez pisarza miast posiada swój klimat, swoje barwy, znaki szczególne, tętni teraźniejszością, oddychając powietrzem historii. Autor jest przy tym wnikliwym, uważnym obserwatorem ludzi - ich postaw, zachowań, charakterów, nierzadko osuwa się z radości i zachwytu w odczuwanie przemijania i melancholię. Dostrzega jasną i ciemną zonę codzienności, stwarzając tym samym dla czytelnika niezwykłą, uniwersalną możliwość odbierania różnoimiennych stron dziewiętnastowiecznego podróżowania. Podobna perspektywa wysuwa się z drugiego źródła włoskich inspiracji autora Improwizatora, mianowicie z opublikowanego w roku 1842 zbioru szkiców odnoszących się do rozpoczętej jesienią 1840 roku podróży po Europie i Wschodzie - tomu zatytułowanego Bazar poety. Poza opisami, utrwalającymi obrazy Niemiec, Grecji, Turcji, są tutaj także odniesienia do Italii utrzymane $\mathrm{w}$ konwencji znanej już z wcześniejszych notat autorskich czy wspomnianego Improwizatora. Andersen był we Włoszech jeszcze przed opublikowaniem Improwizatora, co wiadomo z jego zapisków z lat 1833-1834; wrażenia i wiedza z tej pierwszej podróży na Półwysep Apeniński składają się na kształt literacki włoskich tekstów popodróżnych Duńczyka ${ }^{6}$.

Co łączy przywołane tutaj teksty? Jaki jest wymiar tej narracji? Otóż scala je przede wszystkim Andersenowska fascynacja, oczarowanie Italią z jednej strony, z drugiej zaś różnoimienne refleksje, rozważania, jak również aura przerażenia wkomponowana $\mathrm{w}$ odbiór i ocenę Włoch. Cechą prymarną tych tekstów (traktowanych w lekturze wspólnie) jest zatarcie granic pomiędzy realnością a wyobraźnią oraz usensualnienie dyskursu. Zapisy Andersena silnie stymulują wyobraźnię, uwalniają namysł filozoficzny, poszerzają wielokontekstowość postrzegania przestrzeni miejskiej. Dzięki takiemu poszerzeniu percepcji, pobudzeniu wyobraźni, wydobyciu $\mathrm{z}$ zawieszenia różnorakich horyzontów znaczeniowych oraz za intensyfikacją sensualnej obserwacji stoi lepsze, bardziej dogłębne, szerokokątne widzenie i rozumienie kultury, ludzi, a przede wszystkim samego ducha Italii .

\footnotetext{
${ }^{5}$ Zob. Płaszczewska O., Italia Hansa Christiana Andersena (z rozważań nad XIX-wieczną „podróżą włoską”), [w:] „Wielogłos. Pismo Wydziału Polonistyki UJ” 1/2007, s. 81-96.

6 Tamże, s. 82-85.

${ }^{7}$ Tamże, s. 86-89.
} 


\section{1. „Cudownie piękne Włochy”(I, s. 60)}

W przywołanym wyżej artykule Italia Hansa Christiana Andersena, Olga Płaszczewska rozważając XIX-wieczną „podróż włoską” poddała wnikliwej analizie zapisy popodróżne autora z Odense zamieszczone w Bazarze Poety. Dla mnie interesujące pozostają te najwcześniejsze opisy ważniejszych miast włoskich, które pojawiają się $\mathrm{w}$ kilku miejscach $\mathrm{w}$ pierwszej powieści dramatopisarza duńskiego, w Improwizatorze.

\section{R z y m}

W spojrzeniu Andersena Rzym to miasto gęsto zabudowane, w którym ustawicznie splata się historia z teraźniejszością. Mieszają się tu: współczesny ruch, różnoimienna codzienność, bieda versus wszechobecne ruiny, jak na przykład Koloseum wiejące chłodem, trawione upływającym czasem i emitujące irracjonalny lęk przed przeszłością (I, s. 41-42); „szczątki dawnych świątyń”, „marmurowe nagłówki filarów leżące w trawie” (I, s. 40).

Zupełnie inna perspektywa Rzymu wyłania się z opisu Andersena obserwującego tamtejszy karnawał. Ruch, gwar, rozgardiasz, niezliczona ilość przebierańców, wachlarzy i masek - to znaki rozpoznawcze wydarzenia rzymskiego. Ulice najczęściej zamieniały się w sale balowe (I, s. 93), „ze wszystkich okien, balkonów, powznoszonych lóż zwieszały się kolorowe kobierce; powozy toczyły się jeden za drugim, zapełnione po większej części maskami" (ibidem), przejeżdżały pojazdy aż do przesady udekorowane, że nierzadko „wyglądały jak ruchome altanki” (ibidem). Mnóstwo gapiów, spacerowiczów, różnorakich dźwięków, kolorów, strojów. Gdzie nie spojrzeć wszędzie niezliczona ilość „arlekinów z grzechotkami u nóg i ramion” (I, s. 94), ludzie chodzący na szczudłach, tłum tańczących, występy, przedstawienia, confetti, teatr, „girlandy z lamp i świec” (I, s. 120). Wydaje się, iż wszystkie wymienione elementy - od ruin poczynając a na maskach, świecidełkach, strojach karnawałowych kończąc - pełnią tutaj wyraźną funkcję bodźca melancholijnego dla namysłu filozoficznego, otwierającego refleksję nad czasem, zmiennością losu, przemijaniem, bezsilnością człowieczą i wreszcie śmiercią. Dostrzeganie tych kategorii w takich zdarzeniach, jak karnawał, maskarada, bal, udobitnia filozoficzne predylekcje narratora w interpretowaniu rzeczywistości. Ma również związek (i to $\mathrm{w}$ stopniu przeważającym) $\mathrm{z}$ osobliwym postrzeganiem teatru przez autora Baśni mojego życia (niespełnione plany aktorskie młodego Andersena, jego permanentne zainteresowania sztuką teatralną $\left.{ }^{8}\right)$.

8 Zob. tamże, s. 93. 
Centralny w opisie Rzymu motyw karnawału wydobywa również ulotność radości, szczęśliwości, wzniosłości, święta w egzystencji, jej krótkotrwałość udobitnia niestety marność doczesności, chroniczne ciążenie ku vanitas. Andersen doskonale wyraził tę kondycję. „Wspominałem - pisał wesołe dni karnawału, które mnie nowym natchnęły życiem, a teraz z całą swą rozkoszą znikły. (...) Wszystko było jakby nagle przemienione; wszystkie drzwi i okna pozamykane, na ulicach i Corso ludzi mało. Gdzie wczoraj ledwo się można było przecisnąć przez różnobarwny tłum, dziś uwijało się tylko kilku więźniów w białych, w szerokie niebieskie pasy ubiorach, zamiatając confetti, które jak grad leży na ulicach. Wychudła szkapa z wiązką siana u boku, które ciągle skubała, ciągnęła wózek, na który śmieci wrzucano. (...) Wszyscy wyjeżdżali do Neapolu lub Florencji - Rzym miał przez całe pięć długich tygodni, od środy popielcowej do Wielkiejnocy, spoczywać jak martwy" (I, s. 120-121). Autor zasugerował jednoznaczny stosunek do samego karnawału jako krótkotrwałej, jednorazowej przygody i związanych $\mathrm{z}$ nią przeżyć, zdobytych doświadczeń. Zabawa, beztroska, rozrywka są chwilowe, afirmują „tu i teraz”, wywiedzione z Horacjańskiego projektu filozoficznego chwytanie chwili, korzystanie $\mathrm{z}$ każdego dnia, unikanie marnowania mijających momentów, zamknięte w słynnej łacińskiej formule carpe diem. Postawa ta jest jednak trampoliną do wypowiedzenia prawdy uniwersalnej, mocnym akordem potwierdzona egzystencjalna zasada kresu wszystkiego. $\mathrm{Z}$ osobistych przeżyć, doznań, spostrzeżeń autora osiągniętych $\mathrm{w}$ centrum karnawału rodzi się głęboki smutek, że wszystko jest w dookolności chwilowe, fragmentaryczne, momentalne i ostatecznie śmiertelne.

\section{$\mathrm{N}$ e a p o 1}

Andersen zobaczył Neapol wieczorem, przybywając na reprezentatywną „wspaniałą ulicę Toledo, Corso Neapolu” (I, s. 171). W pierwszym oglądzie widać było wspaniałość wręcz nierzeczywistość tego miasta. Wszędzie „sklepy, przed nimi stoły z pomarańczami i figami oświetlone lampami i kolorowymi latarkami. Cała ulica, z niezliczonymi światełkami pod gołym niebem, wyglądała jak strumień gwiazdami posiany" (tamże). Oglądający uległ urokowi kamienic z dużymi oknami i balkonami.

Dostrzegał ruch uliczny i miejski hałas: „Powozy migały w różnych kierunkach, a konie ślizgały się na gładkich płytach z lawy, którymi ulica została wyłożona" (tamże), gdzie spojrzeć jeździły kabriolety dwukołowe, rozwożąc mieszkańców w różnych kierunkach, zewsząd dobiegały krzyki, śmiechy, głosy, przeróżne rozmowy a katarynki i pozytywki zwiększały miejską kakofonię, której dodatkowo „wtórował śpiew kobiet” (I, s. 172). 
Ciekawy był także efekt opisywanych obserwacji - Andersen jako turysta odkrywał w sobie poczucie odmiany, egzotyki, a nawet - pełni życia: „Czułem, że jestem w innym świecie; otaczało mnie powietrze gorętsze i życie pełniejsze niż to, które dotąd znałem. Rzym - wyznawał dalej narrator - wydawał się grobem w porównaniu z (...) śmiejącym się Neapolem" (tamże).

Doznania narratora zmieniły się, gdy znalazł się na Largo del Castello największym placu nieopodal portu. Ponownie wywiedzione z osobistych pasji fascynujące okazały się: „oświetlone teatry, a przed nimi różne obrazy przedstawiające główne sceny granych sztuk” (tamże), czy też „mały teatr marionetek, jeszcze mniejszy zaś urządzony był na dworze, gdzie poliszynel wyprawiał pocieszne skoki, gwizdał, skrzeczał i komiczne prawił mowy" (tamże). De novo, jak w Rzymie, zachwycił autora radosny hałas, karnawałowy klimat $^{9}$, tłum, oklaski, gromady ludzi śpiewających albo grupki śmiałków odgrywających własne, uliczne przedstawienia.

\section{A m a lf i}

Amalfi to miasteczko piękne i malownicze: „wyzierające spośród winnic” (I, s. 227), zbudowane na tarasach skalnych i nazwane przez autora „kwitnącym ogrodem” (tamże). Miasto jak obraz „wisi nad brzegiem morskim wysoko, na stoku góry, świecąc z dala białymi domkami o płaskich wschodniej budowy dachach, a wyżej nad nim zielenią się winnice” (tamże). Jest ponadto „dziwnie spiętrzone; pomiędzy wysokimi kamienicami ciągnęły się ulice wąskie jak korytarze” (I, s. 228), jego fizjonomię tworzą wąskie uliczki „między murami i ścianami skał" (I, s. 229), wijące się i przypominające labirynt przejść, przesmyków, zaułków, ulic. Most, mały plac w centrum miasta, letni krajobraz i „miłe, ciepłe powietrze” (tamże); tarasy widokowe w wystających skałach, skąd obserwować można piękne zatoki, cudowna woń, niezwykła roślinność z aloesami, mirtami, winoroślami na czele, „a wszędzie uwijały się, brzęcząc, prześliczne, żywych kolorów owady” (tamże). Malowniczo wyglądały przede wszystkim domki i małe ogródki z rajską roślinnością. „Nawet na dachu był śliczny ogródek z pomarańczy i bujnych wiklin, które jak aksamitne zielone kobierce zwieszały się na ściany (...); kwitło mnóstwo róż” (tamże).

W formie cząstkowego podsumowania można stwierdzić, że takie miasta jak Neapol i Amalfi wydają się podróżnikowi ze Skandynawii miejscami nie $\mathrm{z}$ tego świata. Położenie geograficzne, przyroda przypominająca hesperyjskie

\footnotetext{
9 Por. interesujący opis karnawału w Neapolu autorstwa Carla Ludwiga Törnberga, przypominający w wielu miejscach opis Andersena: Carl Ludwig Törnberg, Från karnevalen i Napoli / Z karnawału w Neapolu, [w:] „Ny illustrerad tidning” 10 april 1886, nr 15, s. 121-124. Tłumaczenie własne.
} 
ogrody, cudowni, przyjaźni i radośni, chciałoby się powiedzieć, „słoneczni” ludzie to doskonały materiał literacki dla twórcy z dalekiej, ciemnej i zimnej Północy. Przywołane wyżej reprezentatywne fragmenty charakterystyk Neapolu i Amalfi objawiają się Andersenowi jako piękne malowidła, osobliwe, wręcz bajeczne, świeże witalistyczne pejzaże. Te szalenie malarskie (i poetyckie jednocześnie) miejsca rozbudzają w narratorze uczucia łagodne, radosne, miłe i wzniecają postrzeganie estetyczne krajobrazu (emitują też efekt terapeutyczny zwłaszcza dla człowieka z Północy!). Są jednak chwilowe - zobaczone w drodze, w podróży, w krótkim zatrzymaniu się, byciu tam „na moment”. Za radością, nietrwałym uniesieniem stoi bowiem nostalgia, tragiczne przeświadczenie narratora, że to tylko chwila.

\section{P o m p e j e}

Główna ulica miasta - ulica grobów - nazwana jest ulicą Długą. Przykuwa tu uwagę duża ilość pomników. Szeregi domów - pisze autor - „patrzyły ku mnie jak kościotrupy jamami bez oczu. Dookoła widać było ślady trzęsienia ziemi, które przed owym wielkim spustoszeniem miasto nawiedziło" (I, s. 188). Wszędzie ślady zniszczenia, śmierci, zastygłe w kształtach lawy, „wszystko było martwe, tylko otaczająca nas wielka scena natury oddychała życiem; (...) wszystko to przedstawiało scenę, na której Pompeja wydawała się jak chór $\mathrm{w}$ tragedii opiewający potęgę anioła śmierci. Widziałem go tutaj w jego własnej postaci ze skrzydłami z czarnych popiołów i płynącej lawy, które nad wsie i miasta roztacza" (I, s. 190). Opis wizyty w Pompejach wyraża bezbrzeżną refleksję na temat życia i śmierci, stanowi również pogłębienie namysłów filozoficznych, przewijających się przez cały tekst Improwizatora. Ruiny, grobowce, roztrzaskane przez czas budowle czy okaleczone rzeźby, prezentują się tu jako figury nostalgii, podsycając indywidualne zapatrywania narratora, intensyfikując doświadczenie tamtej smutnej dawności.

\section{Narracja paralelna. Gianrico Carofiglio}

Jak widać, w narracjach Andersena miejskość jawi się zasadniczo jako pasmo wrogie, nieodpowiednie dla jednostki twórczej, teren nieprzewidywalny, tajemniczy i niewiadomy. Podmiot przeżywa miejską przestrzeń jako nowoczesne więzienie, które niszczy wyobraźnię. Labiryntowość przestrzeni, urbanistyczna martwota budzi nieodparcie lęk, wywołuje uczucie zagrożenia, niepewności. 


\subsection{Porównanie z obrazami mieszkańca Italii}

Niezwykle podobnie przedstawił przestrzeń miejską urodzony w 1961 roku pisarz włoski, prokurator - Gianrico Carofiglio. Jednym z głównych bohaterów jego kryminałów jest rodzinne włoskie miasto Bari. Jest ono „zawieszone”, „rozpięte” w narracjach tych książek niemal jak mgła, co potęguje aurę kryminalną. Bari, tak jak niektóre miasta włoskie odczytywane przez Andersena, jest pełne tajemniczej dawności, nierzadko groźnej, kryjącej wiele mrocznych zdarzeń. Tajemnice te wzmacnia obecność Starego Miasta - Bari przedwiecznego - najczęściej wieczornego lub nocnego, w którym perspektywa czasowa uintensywnia różnoimienną zagadkowość świata przedstawionego. Bari Carofiglio jest senne, oniryczne, nieoczywiste - co wzmaga efekt tajemniczości, strachu. Z ulic dobiegają „dziwnie stłumione odgłosy. Jak dźwięki sprzed wielu lat”"10, ulice są najczęściej „puste i mroczne”11, „najciemniejsze i najbardziej puste” ${ }^{12}$, najbardziej prawdziwe jest to miasto $\mathrm{w}$ nocy, o zmroku $-\mathrm{z}$ „ciemności na zewnątrz dobiegały przytłumione, niewyraźne odgłosy chwili zawieszonej w czasie”13, „po opustoszałych ulicach"14 zawiewa jedynie wiatr.

Czytelnik jest stymulowany ograniczającym strachem, bowiem tak jak bohater wsłuchuje się nieustannie $\mathrm{w}$ "hałasy dochodzące $\mathrm{z}$ ulicy"15 (nie zapowiadające $\mathrm{W}$ toku narracyjnym nic pozytywnego) - tego „naprawdę pustego miasta"16. U włoskiego pisarza bardzo często pojawia się ograniczające jednostkę środowisko wodne. Najczęściej pada deszcz, jak na przykład w Świadku mimo woli ${ }^{17}$, Bari „po deszczu wyglądało jakby pokryte czarnym lśniącym lakierem” ${ }^{18}$, nierzadko funkcjonowało „wśród mokrego i plugawego mroku”19, a każda „pusta ulica lśniła od deszczu”20; „świt był siny, niebo

\footnotetext{
10 Carofiglio G. (2012). Ponad wszelką wątpliwość, przekład J. Wachowiak-Finlaison, (tytuł oryginału: Ragionevoli dubbi, Palermo 2006). Warszawa: Wydawnictwo W. A. B., s. 258.

${ }^{11}$ Carofiglio G. (2012). Ulotna doskonałość, przekład J. Wachowiak-Finlaison, (tytuł oryginału: Le perfezioni provvisorie, Palermo 2010). Warszawa: Wydawnictwo W. A. B., s. 42.

${ }^{12}$ Carofiglio G. (2009). Z zamkniętymi oczami, przekład J. Ugniewska (tytuł oryginału: Ad Occhi Chiusi, Palermo 2003). Warszawa: Wydawnictwo W. A. B., s. 173.

${ }^{13}$ Carofiglio G. Ulotna doskonałość, dz. cyt., s. 212.

14 Tamże, s. 302.

${ }^{15}$ Carofiglio G. Świadek mimo woli (2009), przekład J. Ugniewska, (tytuł oryginału: Testimone inconsapevole, Palermo 2002). Warszawa: Wydawnictwo W. A. B., s. 259.

16 Tamże, s. 157.

17 Zob. s. 56-57.

18 Carofiglio G. Ulotna doskonałość, dz. cyt., s. 42.

19 Tamże, s. 42-43.

20 Tamże, s. 145.
} 
w kolorze mysim, a kałuże tak czarne, że nic się w nich nie odbijało"21. Odczucie obcości i uwięzienia wzmaga dodatkowo nieustannie wiejący wiatr („na dworze panował chłód, głównie z powodu wiejącego mistralu”22; „przed świtem zaczął wiać mistral i już w pierwszych jego podmuchach poczułem dreszcze"23).

Bari okazuje się być miastem infernalnym - obcym, demonicznym, działającym w permanencji różnoimiennej opresji. Pisarz podkreśla często jego niepoznawalność, lokując nierzadko akcję w „nieznanych częściach miasta”24 nocą - znamienne, że mecenas Guerrieri najczęściej lubi spacerować właśnie nocą po miejscach opuszczonych, widmowych, emanujących niepokojem. „Składy, opustoszałe magazyny, warsztaty samochodowe, wygasłe kominy, zamknięte od dziesięcioleci place fabryczne, pełne chwastów, dzikich psów, sów i nieuchwytnych miejskich lisów”25 - udobitniają opresyjny charakter miasta, przestrzeń trudną, w której człowiek wrażliwy, twórczy nigdy nie poczuje się u siebie, nie znajdzie wewnętrznej energii, motywacji kluczowej dla kształtowania doświadczenia wewnętrznego.

W takiej przestrzeni miejskiej człowiek nie może być ustawiany wobec aksjologii pełnej, bowiem zawsze podlegać będzie jakiejś redukcji, zaplątaniu, osłabieniu. W obszar ontologiczno-aksjologicznych refleksji wpina Carofiglio refleksję temporalną. „Czas - pisze - napinał się jak łuk, gotowy wystrzelić nas nie wiadomo gdzie"26 - czym podkreśla wątpliwą formę człowieczego istnienia, jej słabość ontyczną. Carofiglio uzmysławia ludzką kondycję z bazową jej kategorią niestałości i niepokoju, niemocy, samotności, poczucia pustki ${ }^{27}$. Włoski pisarz, opowiadając $\mathrm{w}$ kilku planach narracyjnych o opresyjnej miejskości, mówi jednocześnie o rudymentarnej właściwości egzystencji, mianowicie o przemijaniu. Tak, jak piękne, puste, „wypełnione ciężkimi zapachami, brudne, niepokojące"28 jest jego Bari, tak wypełniona jest ustawicznym poczuciem straty, lęku każda minuta człowieczego bycia. „W powietrzu wyczuwałem melancholię i coś jeszcze, czego nie potrafiłem uchwycić" 29 - przemijanie bowiem jest nieuchwytne, autor celowo nie mówi o

\footnotetext{
${ }^{21}$ Carofiglio G. Świadek mimo woli, dz. cyt., s. 64.

22 Carofiglio G. Ulotna doskonałość, dz. cyt., s. 40.

${ }^{23}$ Carofiglio G. Świadek mimo woli, dz. cyt., s. 259.

${ }^{24}$ Carofiglio G. Ulotna doskonałość, dz. cyt., s. 40.

${ }^{25}$ Tamże, s. 42.

${ }^{26}$ Carofiglio G. Świadek mimo woli, dz. cyt., s. 124.

27 Zob. Pascal B. (1999). Myśli, przekład T. Boy-Żeleński. Warszawa: Pax, s. 95-98.

${ }^{28}$ Carofiglio G. Z zamkniętymi oczami, dz. cyt., s. 127.

${ }^{29}$ Carofiglio G. Świadek mimo woli, dz. cyt., s. 124.
} 
tym wprost, zostawiając margines refleksyjności czytelnikowi. Kuriozalna, mroczna, brzydka zewnętrzność miasta infernalnego, również tu wchłania człowieka z właściwościami.

\section{Tekst - logos - witraż filozoficzny}

Wychodząc od prymarnej topiki ujętych w niniejszej egzegezie kategorii i uwzględniając poczynione analizy i interpretacje, w strategiach pisarskich wybranych przeze mnie pisarzy, wyraźnie zauważyć można obecność palimpsestowego kontekstu filozoficznego. Ma on niezwykle pojemny zakres i przede wszystkim trwałą, uniwersalną wartość. Wybrani tu pisarze, wykorzystując znany repertuar topiki literackiej oraz splecionej z nią filozofii, osiągają efekt uniwersalizacji przekazu - tworząc osobliwy powieściowy witraż literacko-filozoficzny. Dzięki znamiennej aktualności ich powieści, przenikliwości myślowej autorów, wciąż de novo można tłumaczyć człowieka i nieprzeniknioną tajemnicę egzystencji. Autorzy - dosłownie i metaforycznie opowiadają o czasie, o temporalnej i wanitatywnej kondycji człowieka i doczesności, o przemijaniu i opresji. Główną zbieżność dostrzegam $\mathrm{w}$ zaprezentowaniu ambiwalencji egzystencji (świadomość tragiczna, samoświadomość słabości), szczególnie sytuacji człowieka - owej „trzciny najwątlejszej” (Pascal) wrzuconej w nicość bytu. Zbliża ich również portret jednostki spowitej pajęczyną nieuchronnych paradoksów istnienia.

\subsection{Ważny kontekst filozoficzny}

Podobną materią opalizuje myśl filozoficzna Gilles'a Deleuze’a (1925-1995). Deleuzjański wywód krąży wokół tych samych kategorii i fenomenów egzystencjalnych, jak wskazane wyżej. Powieściopisarze, podobnie jak Deleuze, ujawniają naturę sensu opartego o nonsens, tłumaczą normalne przez patologiczne, sens przez nonsens. „Nonsens - pisze Deleuze w Logice sensu - to coś, co nie ma sensu, ale właśnie jako taki stanowi zaprzeczenie jego nieobecności, dokonuje aktu nadania sensu. Oto co należy rozumieć przez prawdziwy nonsens" ${ }^{30}$. Zaskakująca jest również u tych autorów zbieżność, że tak jak główną składową refleksji Deleuze’a jest przekonanie, że myśl nie zna granic (Deleuze’a koncepcja myśli nomadycznej), tak wektor egzystencji wyznacza potrzeba nietworzenia granic i wszelki ruch, nieprzerwany proces bezustannego przemieszczania, ciągła wędrówka (podróż) „po” doświadczenia

${ }^{30}$ Deleuze G. (2011). Logika sensu, przeł. G. Wilczyński, przekład przejrzał M. Herer, Warszawa: Wydawnictwo Naukowe PWN, s. 107-108. 
kształtujące mentalnie i emotywnie. Podstawowe problematy stawiane przez pisarzy dotykają zatem przestrzeni zagadnień metafizycznych, stanowiąc próbę odkrycia istoty oraz sensu ludzkiej egzystencji. Metafizyka otwiera drogę li tylko do duchowej wolności, jest kluczem do bramy właściwego poznania i szansą uczestnictwa $\mathrm{w}$ transcendencji. $\mathrm{W}$ toku wydarzeń wpisanych $\mathrm{w}$ teksty literacko-filozoficzne widzimy, że słowa tworzą strukturę hierarchiczną, że istnieją $\mathrm{w}$ porządku ściśle wyznaczonym przez intencję autora. Zdarza się, że ten porządek nie jest $\mathrm{w}$ stanie ukryć wewnętrznych sprzeczności tekstu, przeciwnie, uwypukla odczucie niedorzeczności obrazów przedstawionego świata, ale efekt taki jest wynikiem drogi, którą autorzy wybrali dla realizacji swych zamierzeń. W przywołanych tutaj utworach odpowiedzi na pytania o sens i istotę bytu, ukryte są $\mathrm{w}$ obrazach codzienności i tajemniczości miasta. Przenikanie się wzajemne wymiaru powszedniości z przestrzenią tajemnicy tworzy oblicze rzeczywistości. Autorzy pokazują, w jaki sposób obecna w konkretnych przejawach codzienności tajemnica przemawia do człowieka i jak jest on ślepy na to, co rysuje się tuż przed jego oczyma. Dlatego też wyłania się z tych tekstów portret Człowieka Prawdziwego - otwartego na najgłębsze poznanie i twórczego.

\section{4. „Lektura czasu”}

W tekstach Duńczyka i Włocha odkrywamy także silne pragnienie rozpoznania fenomenu czasu - ową Deleuzjańską „lekturę czasu”31 - władania wymiarami istnienia, pobudzania jaźni transcendentalnej, aby wkraczała na najwyższy poziom duchowej egzystencji. Jaźń transcendentalna zdaje się tu być tożsama z Nietzscheańską wolą mocy. Człowiek prawdziwy jest zatem ostatecznie wieczną emanacją istoty absolutnej. Dominantą jego natury jest nieustanne dążenie do doskonałości oraz penetracja własnej jaźni w poszukiwaniu wewnętrznej głębi. Aktywność człowieka prawdziwego koncentruje się na konstruowaniu pomostów między światem zewnętrznym a przestrzenią ducha. Jednocześnie jest on transcendentny wobec otaczającej go rzeczywistości, nie realizuje bowiem modelu życia preferowanego przez innych ludzi, lecz ma odwagę podążać szlakiem własnych ambicji. Jedną $\mathrm{z}$ nich jest pragnienie rozpoznania wszystkich pierwiastków własnego świata wewnętrznego i pojednanie sprzecznych wektorów ich działania. Człowiek prawdziwy nosi

\footnotetext{
${ }^{31}$ Deleuze G. Logika sensu, dz. cyt., s. 224.
} 
cechy nadczłowieka Fryderyka Nietzschego ${ }^{32}$ (1844-1900), obdarzonego wola mocy i podległego prawu wiecznego powrotu, ale - zgodnie z założeniami epistemologii Henri Bergsona (1859-1941) - posiada zdolność poznania intuicyjnego. Poznanie intuicyjne jest jego zdaniem nierozerwalnie związane z ideą Absolutu. Dążenie do rozpoznania Absolutu i „dotknięcia” go stanowi nie tylko cel, ale i powinność człowieka. Intuicja zaś jest jedyną drogą pozwalającą dosięgnąć transcendencji33. Dzięki bezpośredniemu zanurzeniu w wydarzeniach powszedniości, w zmiennym i złożonym świecie zjawisk, intuicja, będąca uświadomionym instynktem, wspina się ku Absolutowi. Czas będący kategorią niezwykle istotną zarówno $\mathrm{w}$ bergsonizmie, nietzscheanizmie, jak i w rozważaniach Deleuze’a zdaje się być jedną z postaci Absolutu. Absolut daje się „objąć” jedynie na drodze intuicyjnego oglądu. Czas stanowi istotę rzeczywistości, obnażającą jej właściwą formę. Przestrzeń natomiast deformuje percepcję świata. „Stan mojej duszy, posuwając się naprzód drogą czasu, w sposób ciągły wzbiera trwaniem, które gromadzi" ${ }^{34}$ pisał Bergson. Trwanie zdaje się być podstawą prądu egzystencji, ale w trwaniu towarzyszy twórczy strumień, logos. Według Bergsona „trwanie, to znaczy czas, jest z istoty wielością"35.

W świetle powyższych rozpoznań wyraźniej rysuje się, jak wspomniałem, portret Człowieka Prawdziwego. Człowiek taki jest odzwierciedleniem idei Nietzschego i myśli Bergsona (filozofów często obejmowanych refleksją przez Deleuze’a). Uznaje równoprawność władzy intelektu (koniecznego do władania światem materialnym) oraz intuicji (sięgającej Absolutu poprzez dogłębne przemierzanie ulotnych zjawisk zmiennej codzienności). Jak nadczłowiek z wizji autora Niewczesnych rozważań tworzy i przekształca systemy wartości. Jest też wolny - dzięki sile czerpanej z Bergsonowskiego élan vital oraz z Nietzscheańskiej woli mocy. Wreszcie człowiek ów potrafi dotknąć i rozpoznać tajemnicę swego istnienia $\mathrm{w}$ czasie i przestrzeni. Jak widać, pytania filozofii nigdy nie tracą wagi aktualności, inspirują i śmiało wypełniają trajektorie myśli.

Wróćmy do analizowanych tu powieści. Z jednej strony, ich podmioty „wrzucone” w mechanizmy miast włoskich umacniają się $\mathrm{w}$ poczuciu znikomości ludzkiej egzystencji, z drugiej zaś nie ustają w poszukiwaniach

32 Zob. Deleuze G. (2012). Nietzsche, przeł. B. Banasiak. Łódź: Wydawnictwo Officyna.

33 Zob. Deleuze G. (1999). Intuicja jako metoda, [w:] tenże, Bergsonizm, przeł. P. Mrówczyński. Warszawa: Wydawnictwo KR, s. 5-30.

34 Bergson H. (1988). Pamięć i życie, wybór tekstów G. Deleuze, przeł. A. Szczepańska. Warszawa: Instytut Wydawniczy Pax, s. 6.

35 Deleuze G. Bergsonizm, dz. cyt., s. 81 . 
sposobu zakorzenienia $\mathrm{w}$ doczesności, w municypalności - wyjścia z doczesnych „rozpadlin nonsensu”36 (opresja) i nadania jej Sensu / umocnienia „sfery infrasensu”37 (wolność). Nieustannie przeżywają rozdarcie egzystencjalne - konflikt między poczuciem opresji a pragnieniem wolności. Przezwyciężają poczucie bezradności wobec miasta i wobec przeciwstawnych odpowiedzi, których kultura, z pomocą systemów filozoficznych, udziela na najbardziej rudymentarne pytania. Zdają się wypełniać egzystencję myślą twórczą i prawdziwą, będącą zawsze aktualnym zadaniem człowieka, które Deleuze celnie definiuje permanentnym „produkowaniem sensu”"38. Kluczowymi wydają się tu być dwie kategorie - lęk i temporalność, z których czas jest fenomenem nadrzędnym. W nim istnieje, czy też ma zaistnieć Człowiek Prawdziwy. Jego permanentna walka w przestrzeni codzienności jest zatem walką o wolność zwłaszcza w mieście, sztucznym wytworze kultury.

\section{Dwie narracje. Zakończenie}

Strategia opisu miast włoskich Hansa Christiana Andersena i Giacomo Carofiglio'a zasadza się na dwóch strumieniach narracyjnych. Z jednej strony polega na prezentowaniu piękna natury opisywanej w konwencji bukolicznoarkadyjskiej jako rajskiej doczesności, pełnej jasnej sensualności i optymizmu, harmonii i doświadczanej w pełni wolności. W tym dyskursie - nazwijmy go bukolicznym (Neapol, Amalfi) - Andersen uzewnętrznia znamienną szczęśliwość $\mathrm{z}$ powodu obcowania $\mathrm{z}$ tak zjawiskową krainą geograficzną. Przestrzeń ta wzmaga obecność delikatnych, afirmacyjnych doświadczeń wzbogaconych subiektywizmem i sensualizmem osobniczego odbioru i thumi namysł pesymistyczny. Autor Calineczki zaopatrzony w te elementy chwyta fragmenty lokalnej codzienności, w kształtach harmonii odnalezionej w naturze nobilituje radość chwili, pochwałę egzystencji, witalistyczny optymizm, sugerując istnienie złagodzone naturalnym pięknem i tym samym chwilowo wolne od piętna śmierci.

W drugim dyskursie - pesymistycznym (Rzym, Pompeje, Bari) Andersen i Carofiglio wprost odkrywają przed czytelnikiem gorzką prawdę o przemijaniu i śmierci wszystkiego, o przewadze sił natury, srogiego mechanizmu bytu nad nietrwałą doczesnością, której częścią jest również słaby z gruntu człowiek. Ma to głęboko pesymistyczną wymowę. Uświadomienie, że

36 Deleuze G. Logika sensu, dz. cyt., s. 122.

37 Tamże, s. 136.

${ }^{38}$ Tamże, s. 110. 
za pięknem istnienia stoi też jego śmiertelność, przynosi uniwersalistyczną prawdę o istocie egzystencji, o jej prawidłowości, o losie jednostki i dziejach ludzkości.

W scaleniu tych dwóch dyskursów - wybrani przeze mnie do egzegezy pisarze nakreślili ponadczasowy $-\mathrm{z}$ gruntu filozoficzny - wizerunek egzystencji, udobitnili portret ludzkich pragnień i lęków obecnych $\mathrm{w}$ niewzruszonym mechanizmie bytu - portret zabarwiony komponentami antropologii filozoficznej.

\section{BIBLIOGRAFIA}

Andersen, Ch. H. (2003). Autobiografia. Baśń mojego życia. (tłum. I. Chamska). Łódź: Wydawnictwo Ravi.

Andersen, Ch. H. (2014). Dzienniki 1825-1875. (wybór, tłum. i oprac. B. Sochańska). Poznań: Wydawnictwo Media Rodzina.

Andersen, Ch. H. (2017). Improwizator. (tłum. H. Feldmanowski), (tytuł oryginału: Improvisatoren). Kraków: Wydawnictwo MG.

Andersen, Ch. H. (1857). Improwizator, tom 1 i 2. (tłum. H. Feldmanowski). Poznań: Wydawnictwo L. Merzbach.

Bergson, H. (1988). Pamięć i życie, wybór tekstów G. Deleuze. (przeł. A. Szczepańska). Warszawa: Instytut Wydawniczy Pax.

Carofiglio, G. (2009). Świadek mimo woli. (przekład J. Ugniewska), (tytuł oryginału: Testimone inconsapevole, Palermo 2002). Warszawa: Wydawnictwo W. A. B.

Carofiglio, G. (2009). Z zamkniętymi oczami. (przekład J. Ugniewska), (tytuł oryginału: Ad Occhi Chiusi, Palermo 2003). Warszawa: Wydawnictwo W. A. B.

Carofiglio, G. (2012). Ponad wszelką wątpliwość. (przekład J. Wachowiak-Finlaison), (tytuł oryginału: Ragionevoli dubbi, Palermo 2006). Warszawa: Wydawnictwo W. A. B.

Carofiglio, G. (2012). Ulotna doskonałość. (przekład J. Wachowiak-Finlaison), (tytuł oryginału: Le perfezioni provvisorie, Palermo 2010). Warszawa: Wydawnictwo W. A. B.

Dalager, S. (2007). Podróź w błękicie. Powieść o Hansie Christianie Andersenie. (tłum. B. Sochańska, J. Tamborska). Warszawa: Spółdzielnia Wydawnicza „Czytelnik”.

Deleuze, G. (1999). Intuicja jako metoda. [W:] tenże, Bergsonizm. (przeł. P. Mrówczyński). Warszawa: Wydawnictwo KR.

Deleuze, G. (2011). Logika sensu. (przeł. G. Wilczyński, przekład przejrzał M. Herer). Warszawa: Wydawnictwo Naukowe PWN.

Deleuze, G. (2012). Nietzsche. (przeł. B. Banasiak). Łódź: Wydawnictwo Officyna.

Dymel-Trzebiatowska, H. \& Mrozek-Sadowska, E. (red.) (2006). Andersen 200 lat. Gdańsk: Wydawnictwo Pressfabryka.

Pascal, B. (1999). Myśli. (przekład T. Boy-Żeleński). Warszawa.

Płaszczewska, O. (2007). Italia Hansa Christiana Andersena (z rozważań nad XIX-wieczną „podróżą włoską"), Wielogłos. Pismo Wydziału Polonistyki UJ, 1/2007, s. 81-96.

Ratuszna, H., Wiśniewska, M. \& Wróblewska, V. (red.) (2017). Andersenowskie inspiracje w literaturze i kulturze polskiej. Toruń: Wydawnictwo Naukowe UMK. 
Törnberg, C. L. (1886). Från karnevalen i Napoli / Z karnawału w Neapolu. Ny illustrerad tidning, 10 april 1886, nr 15, s. 121-124.

Wullschläger, J. (2005). Andersen. Życie baśniopisarza. (tłum. M. Ochab, fragm. baśni, listów i dzienników Andersena w przekładzie B. Sochańskiej). Warszawa: Wydawnictwo W.A.B. 
